\title{
Gambaran Diagnosis Malaria pada Dua Laboratorium Swasta di Kota Padang Periode Desember 2013 - Februari 2014
}

\author{
Hans Everald ${ }^{1}$, Nurhayati² ${ }^{2}$ Elizabeth Bahar $^{3}$
}

\begin{abstract}
Abstrak
Pengobatan malaria membutuhkan ketepatan metode pemeriksaan laboratorium yang akurat oleh tenaga laboratorium. Kemampuan tenaga laboratorium perlu dilakukan pengamatan dan pemantauan secara terus menerus untuk menjaga efektivitas pemeriksaan sediaan. Tujuan penelitian ini adalah mengetahui efektivitas diagnosis malaria di laboratorium swasta di Kota Padang. Penelitian ini merupakan uji diagnostik dengan rancangan penelitian Cross Sectional Study terhadap laboratorium swasta di Kota Padang. Sampel yang didapatkan dalam penelitian ini berjumlah 53 slide lalu slide tersebut dibandingkan dengan Cross Checker. Dalam penelitian ini ditemukan bahwa spesies terbanyak adalah Plasmodium vivax dan Plasmodium falciparum. Hasil perhitungan nilai Kappa adalah 0,5 dan perbandingan hasil pemeriksaan parasit $P$. falciparum pada laboratorium swasta adalah $17,8 \%$ dan pemeriksaan Cross checker $1,88 \%$. Untuk $P$. vivax pada laboratorium swasta adalah $43,01 \%$ dan pemeriksaan Cross Checker $13,2 \%$. Kesimpulan hasil ini adalah $P$. faciparum dan $P$. vivax adalah spesies yang sering ditemukan dengan nilai perhitungan Kappa menunjukkan hasil sedang dan terdapat perbedaan hasil pembacaan sediaan antara laboratorium swasta dengan yang dilakukan Cross checker.
\end{abstract}

Kata kunci: malaria, efektivitas, plasmodium falciparum, plasmodium vivax

\begin{abstract}
Treatment of malaria need the accuracy of laboratory examination method by a laboratory personnel. The ability of laboratory personnel is need to doing observation and monitoring continuously to maintain the effectiveness of examination preparation. The objective of this study was to determine the effectiveness diagnosis of malaria in a private laboratory in Padang. This was a diagnostic test with a cross sectional study research design to a private laboratories in the city of Padang. Samples obtained in this study amounted to 53 slides and the slides were compared with Cross Checker. In this study it was found that most species were Plasmodium vivax and Plasmodium falciparum. The result of kappa value was 0,5 and the comparison results of the parasite $P$. falciparum in private laboratories were $17,8 \%$ and the Checker Cross examination are 1,88\%. P. vivax in private laboratories are 43,01\% and the checker cross examination are $13,2 \%$. The conclusion is $P$. vivax and $P$. faciparum are species that is often found by calculating Kappa values showed moderate results and there is a difference between the dosage readings with a private laboratory that performed Cross checker.
\end{abstract}

Keywords: malaria, effectiveness, plasmodium falciparum, plasmodium vivax.

Affiliasi penulis: 1. Pendidikan Dokter FK UNAND (Fakultas Kedokteran Universitas Andalas Padang), 2. Bagian Parasitologi FK UNAND, 3. Bagian Mikrobiologi FK UNAND.

Korespondensi: Hans Everald, E-mail: hans_1301bb@yahoo.co.id, Telp: 0819876901

\section{PENDAHULUAN}

Malaria adalah penyakit infeksi yang disebabkan oleh parasit Plasmodium yang hidup dan berkembang biak dalam sel darah merah manusia dan secara alami ditularkan melalui gigitan nyamuk Anopheles betina. Penyakit malaria sampai saat ini masih menjadi masalah kesehatan umum yang utama di seluruh dunia, terutama di negara-negara berkembang, seperti negara-negara Amerika Latin, Afrika sub-Sahara, Asia Selatan, sebagian Asia Timur (terutama Cina), dan Asia Tenggara, termasuk 
Indonesia. WHO (World Health Organization) menggambarkan hingga tahun 2005 malaria masih menjadi masalah kesehatan utama di 107 negara di dunia. Penyakit ini menyerang sedikitnya 350-500 juta orang setiap tahunnya yang menyebabkan kematian sekitar 1 juta orang setiap tahunnya atau satu bayi atau anak meninggal setiap 30 detik. Diperkirakan masih sekitar 3,2 miliar orang hidup di daerah endemis malaria. Total penderita malaria di dunia mencapai 3,3 juta orang per tahun, terbanyak (80\%) di Afrika dan 20 persen di Asia. ${ }^{1}$

Di Indonesia, penyakit malaria masih endemis di beberapa wilayah. Umumnya di daerah-daerah terpencil dan sebagian penderitanya adalah golongan ekonomi lemah. Pada tahun 2009, Kejadian Luar Biasa (KLB) dilaporkan terjadi di pulau Jawa (Jawa Tengah, Jawa Timur dan Banten), Kalimantan (Kalimantan Selatan), Sulawesi (Sulawesi Barat), NAD dan Sumatera (Sumatera Barat, Lampung) dengan total jumlah penderita adalah 1.869 orang dan meninggal sebanyak 11 orang. KLB terbanyak di pulau Jawa yaitu sebanyak 6 kabupaten/kota. ${ }^{2}$

Angka Klinis Malaria di Sumatera Barat menunjukkan fluktuasi dari tahun ke tahun. Jumlah sediaan darah yang diperiksa sudah meningkat setiap tahunnya. Puncak kejadian malaria di Sumatera Barat selama 10 tahun terakhir ini adalah pada tahun 2009, terdapat 1.357 sediaan positif malaria dari 4.067 buah slide yang diperiksa. Pada tahun 2010 didapatkan 1.104 sediaan yang positif malaria dari 4.701 buah slide yang diperiksa. ${ }^{3}$

Prinsip pengobatan yang dipakai sebagai acuan pada unit kesehatan masyarakat adalah: penyembuhan penderita malaria secara cepat, mengurangi/membasmi parasitemia, mencegah komplikasi dan kematian, mencegah kekambuhan kembali, serta mengurangi penularan. Keberhasilan pengobatan ini memerlukan konfirmasi hasil pemeriksaan mikroskopis yang akurat oleh tenaga mikroskop yang berpengalaman. ${ }^{2}$

Kemampuan seorang tenaga laboratorium baik dalam membuat sediaan darah, mewarnai dan memeriksanya sangat menentukan ditemukannya parasit malaria. Oleh sebab itu ketepatan dan kebenaran pemeriksaan sediaan darah oleh tenaga laboratorium perlu pengamatan dan pemantauan secara terus menerus. Sampai saat ini hal tersebut belum berjalan sesuai dengan yang diharapkan dan belum adanya nilai kesepakatan yang menjadi standar dalam menentukan hasil diagnosis mikroskopis malaria. $^{2}$

Hasil evaluasi Program Penetapan Mutu Eksternal Laboratorium Kesehatan pada pemeriksaan mikroskopis malaria, yang dilakukan oleh Balai Laboratorium Kesehatan, dari 19 laboratorium yang mengevaluasi menggunakan preparat positif malaria, hanya $79 \%$ tenaga laboratorium yang dapat membaca preparat dengan benar. Ditambah lagi rendahnya mutu mikroskop dan pereaksi (reagen) serta kurang terlatihnya tenaga pemeriksa, menimbulkan kendala dalam memeriksa parasit malaria secara makroskopis yang selama ini merupakan standar emas (gold standart) pemeriksaan laboratorium malaria. ${ }^{3}$

Berdasarkan latar belakang diatas perlu diteliti efektivitas diagnosis mikroskopis yang berhubungan dengan kejadian malaria di labotatorium swasta di Wilayah Kota Padang tahun 2013, karena data yang terkumpul tidak terdeteksi oleh Dinas Kesehatan Kota Padang.

\section{METODE}

Penelitian ini dilakukan pada dua laboratorium swasta periode Desember 2013 - Februari 2014. Penelitian ini merupakan suatu penelitian uji diagnostik oleh dua atau lebih petugas mikroskop dengan rancangan cross sectional study. Jumlah sampel dalam penelitian ini adalah 53 sampel. Sampel diperiksa di Laboratorium Parasitologi Fakultas Kedokteran Universitas Andalas

\section{HASIL}

Penelitian efektivitas diagnosis malaria pada laboratorium swasta di Kota Padang dilakukan dengan mengambil sampel slide pada 2 laboratorium swasta yang ada di Kota Padang dari bulan Desember 2013 sampai bulan Februari 2014. Jumlah sampel dalam penelitian ini adalah 53 sampel. Dari jumlah tersebut, ditemukan 20 slide positif pada pemeriksaan laboratorium swasta, sedangkan pada pemeriksaan cross checker ditemukan 8 slide positif. 


\section{Distribusi Frekuensi Malaria dari Hasil Pemeriksaan berdasarkan spesies}

Distribusi frekuensi malaria dari hasil pemeriksaan berdasarkan spesies dapat dilihat pada Tabel 1.

Tabel 1. Distribusi frekuensi malaria berdasarkan spesies Plasmodium di Laboratorium Swasta di Kota Padang selama bulan Desember 2013 sampai bulan Februari 2014.

\begin{tabular}{|c|c|c|c|c|c|c|}
\hline \multirow[t]{2}{*}{ No. } & \multirow[t]{2}{*}{ Plasmodium } & \multicolumn{2}{|c|}{ Laboratorium 1} & \multicolumn{2}{|c|}{$\begin{array}{c}\text { Laboratorium } \\
2\end{array}$} & \multirow[t]{2}{*}{ Jmh } \\
\hline & & $(+)$ & $(-)$ & $(+)$ & $(-)$ & \\
\hline 1 & P. falciparum & - & - & 1 & 9 & 10 \\
\hline \multirow[t]{2}{*}{2} & \multirow[t]{2}{*}{ P. vivax } & \multirow[t]{2}{*}{77} & \multirow[t]{2}{*}{21} & \multirow[t]{2}{*}{31} & \multirow[t]{2}{*}{40} & 16 \\
\hline & & & & & & 9 \\
\hline 3 & P. malariae & - & - & - & - & - \\
\hline 4 & P. ovale & - & - & - & - & - \\
\hline \multirow[t]{4}{*}{5} & P. knowlesi & - & - & - & - & - \\
\hline & Jumlah & 77 & 21 & 32 & 49 & $\overline{179}$ \\
\hline & $\%$ & 43,01 & 11,73 & 17,87 & 27,39 & 100 \\
\hline & \multicolumn{5}{|c|}{ Jumlah Sediaan Darah yang Diperiksa } & 179 \\
\hline
\end{tabular}

Pada Tabel 1 dapat dilihat bahwa hanya spesies $P$. falciparum dan $P$. vivax yang ditemukan pada slide. Tidak ditemukan spesies $P$. malariae, $P$. ovale dan P. knowlesi.

\section{Perbandingan Hasil Pemeriksaan Cross Checker berdasarkan Hasil Positif atau Negatif \\ Perbandingan Hasil Pemeriksaan Cross} Checker berdasarkan Hasil Positif atau Negatif dapat dilihat pada Tabel 2.

Tabel 2. Perbandingan hasil pemeriksaan laboratorium swasta dengan pemeriksaan Cross Checker berdasarkan positif atau negatif parasit malaria.

\begin{tabular}{ccccc}
\hline Pemeriksa & \multicolumn{4}{c}{ Cross Checker } \\
\hline \multirow{4}{*}{ Swasta } & Hasil & Positif & Negatif & Jumlah \\
\cline { 2 - 5 } & Positif & 8 & 12 & 20 \\
& Negatif & 0 & 33 & 33 \\
\cline { 2 - 5 } & Jumlah & 8 & 45 & 53 \\
\hline
\end{tabular}

Pada Tabel 2 ditemukan 20 (37,7\%) sampel positif pada laboratorium swasta dan 8 (15,09\%) sampel positif pada Cross Checker. Ditemukan juga 33 sampel negatif pada laboratorium swasta dan 45 sampel negatif pada Cross Checker.

\section{Perbandingan Hasil Pemeriksaan Cross Checker berdasarkan Spesies}

Perbandingan Hasil Pemeriksaan Cross Checker berdasarkan Spesies dapat dilihat pada Tabel 3.

Tabel 3. Perbandingan hasil pemeriksaan Laboratorium swasta dengan pemeriksaan Cross Checker berdasarkan spesies malaria.

\begin{tabular}{ccccccc}
\hline $\begin{array}{c}\text { Pemeriks } \\
\text { aan }\end{array}$ & $\begin{array}{c}\boldsymbol{P} . \\
\text { falcipa } \\
\text { rum }\end{array}$ & $\begin{array}{c}\boldsymbol{P} \text { viv } \\
\text { ax }\end{array}$ & $\begin{array}{c}\boldsymbol{P} \text { mala } \\
\text { raie }\end{array}$ & $\begin{array}{c}\boldsymbol{P} . \\
\text { ova }\end{array}$ & $\begin{array}{c}\boldsymbol{P} . \\
\text { kno }\end{array}$ & $\begin{array}{c}\text { Jmh } \\
\text { wlesi }\end{array}$ \\
\hline Swasta & 1 & 19 & - & - & - & 20 \\
Cross & 1 & 7 & - & - & - & 8 \\
Checker & & & & & & \\
\hline
\end{tabular}

Pada Tabel 3 ditemukan 20 sampel positif pada laboratorium swasta dimana 1 slide dengan spesies $P$. falciparum (5\%) dan 19 slide dengan spesies $P$. vivax (95\%). Pada cross checker ditemukan 8 sampel positif, yaitu 1 slide dengan spesies $P$. falciparum (12,5\%) dan 7 slide dengan spesies $P$. vivax $(87,5 \%)$.

\section{Perbandingan Hasil Pemeriksaan Cross Checker berdasarkan Parasite Count}

Peneliti tidak dapat menemukan hasil untuk pemeriksaan Cross Checker berdasarkan Parasite Count karena laboratorium swasta yang diteliti tidak menyimpan data atau tidak melakukan metode ini.

\section{PEMBAHASAN}

\section{Distribusi Frekuensi Malaria dari Hasil}

\section{Pemeriksaan berdasarkan spesies}

Hasil penelitian pada 179 sampel slide malaria pada laboratorium swasta di Kota Padang ditemukan bahwa frekuensi parasit malaria berdasarkan spesies yaitu pada spesies p. vivax $43,01 \%$ dan p. falciparum $17,87 \%$ dari total sampel.

Tingginya frekuensi parasit $p$. vivax dan $p$. falciparum sesuai dengan penelitian Irawati pada tahun 2009 tentang "Studi Keragaman Struktur Gen MSP1 Plasmodium Falciparum di Daerah Endemi Malaria Pegunungan dan Pantai Sumatera Barat." menunjukkan bahwa Plasmodium falciparum (75\%) sebagai spesies yang paling banyak menyebabkan malaria. Penelitian lain juga menjelaskan bahwa Plasmodium falciparum mendominasi insiden malaria 
di daerah endemis Kenagarian Sungai Pinang, Kabupaten Pesisir Selatan, Sumatera Barat. Hal ini sesuai dengan sumber yang menyatakan bahwa spesies yang banyak dijumpai di Indonesia adalah Plasmodium falciparum dan Plasmodium vivax. ${ }^{4-5}$

\section{Perbandingan Hasil Pemeriksaan Cross Checker berdasarkan Hasil Positif atau Negatif}

Hasil perhitungan nilai Kappa pada penelitian ini dapat diketahui bahwa kesepakatan hasil diagnosis $P$. falciparum dan P.vivax antara petugas mikroskop laboratorium swasta di Kota Padang dengan Cross Checker termasuk dalam kategori sedang dengan nilai 0,45 .

Hal ini berbeda dengan penelitian Chadijah pada tahun 2006 yang mendapatkan nilai Kappa sebesar 0,29 dan masuk dalam kategori kurang. Perbedaan ini dapat disebabkan oleh perbedaan kemampuan oleh petugas laboratorium yang diteliti oleh Chadijah dan dikonfirmasi langsung dalam penelitian tersebut. 6

Kemungkinan penyebab perbedaan lainnya adalah proses transportasi sampel yang dilakukan dari laboratorium swasta ke laboratorium tempat dilakukannya penelitian.

\section{Perbandingan Hasil Pemeriksaan Cross Checker berdasarkan Spesies}

Berdasarkan hasil pemeriksaan laboratorium swasta ditemukan parasit $P$. falciparum sama dengan pemeriksaan Cross checker yaitu sebesar 1,88\%. Untuk $P$. vivax, pada laboratorium swasta ditemukan $35,8 \%$ dari total sampel, sedangkan pada pemeriksaan Cross checker ditemukan 13,20\%.

Hal ini terjadi karena adanya kualitas sediaan yang kurang baik, sehingga sulit untuk diperiksa. Kualitas sediaan darah yang kurang baik menunjukkan bahwa kemungkinan kesalahan disebabkan oleh faktor teknis dan kedisiplinan yang masih kurang serta belum mengikuti standar operasional prosedur laboratorium, sebagaimana yang berlaku dalam program. Faktor kemampuan individu masing-masing petugas mikroskopis juga ikut berperan.

\section{Perbandingan Hasil Pemeriksaan Cross Checker berdasarkan Parasite Count}

Tidak didapatkan hasil Parasite Count karena laboratorium swasta yang diteliti tidak memiliki data atau tidak melakukan prosedur tersebut.

\section{KESIMPULAN}

Frekuensi malaria yang positif di laboratorium swasta di Kota Padang sebanyak 60,88\%.

Frekuensi malaria positif di laboratorium swasta di Kota Padang adalah 37,7\% sedangkan frekuensi malaria positif berdasarkan hasil pemeriksaa Cross Checker 15,09\%. Hasil perhitungan nilai Kappa menunjukkan bahwa kesepakatan antara petugas mikroskopis laboratorium swasta dengan Cross checker, menunjukkan hasil yang sedang.

Frekuensi malaria di laboratorium swasta di Kota Padang berdasarkan spesies $P$. falciparum sebanyak $5 \%$, $P$. vivax $95 \%$, sedangkan spesies $P$. malariae, $P$. ovale dan $P$. knowlesi tidak ditemukan pada sediaan sedangkan berdasarkan hasil pemeriksaan Cross Checker $P$. falciparum 12,5\%, $P$. vivax $87,5 \%$, $P$. ovale dan $P$. knowlesi tidak ditemukan pada sediaan.

Hasil pemeriksaan laboratorium swasta dengan pemeriksaan cross checker berdasarkan parasite count tidak dapat dilakukan karena sampel berdasarkan parasite count tidak didapatkan.

\section{DAFTAR PUSTAKA}

1. Dirjen PP dan PL. Data surveilans epidemiologi tahun 2007. Jakarta. Depkes RI. 2008; 129-34.

2. Depkes RI. Modul epidemiologi malaria. Dirjen Pencegahan dan Pemberantasan Penyakit Menular. Jakarta. Depkes RI. 2000.hlm.67-9.

3. Dinas Kesehatan Propinsi Sumatera Barat. Profil kesehatan tahun 2010. Padang: Dinkes Sumbar; 2010.hlm. 42-6.

4. Nuzulia I. Studi keragaman struktur gen MSP1 Plasmodium Falciparum di Daerah endemi malaria pegunungan dan pantai Sumatera Barat (disertasi). Padang: Fakultas Kedokteran Universitas Andalas; 2009.

5. Aziz D. Epidemiologi malaria di Sipora Kepulauan Mentawai Sumatera Barat (laporan penelitian). Padang: Fakultas Kedokteran Universitas Andalas; 1990. 
6. Chadijah S. Efektifitas diagnosis mikroskopis malaria di Puskesmas Donggala, Puskesmas Lembasada, dan Puskesmas Kalawi, Provinsi
Sulawesi Tengah. Badan Litbang Kesehatan. Departemen Kesehatan Provinsi Sulawesi Tengah: 2006.hlm.143-6. 